\title{
Inflammatory and prooxidant markers in response to periodontal treatment - A case report
}

\author{
Ricardo Andreu ${ }^{1,2 *}$, Sergio Santos-del-Riego ${ }^{2}$ and Francisco Payri ${ }^{3}$ \\ ${ }^{1}$ Dental Clinic, Paterna, València, Spain \\ ${ }^{2}$ Department of Physioterapy Medicine and Biomedical Sciences, University of A Coruña, A Coruña, Spain \\ ${ }^{3} \mathrm{CMT}$, Politechnyc University of València, València Spain
}

\begin{abstract}
\section{Introduction}

\section{Inflammatory markers}

Different studies like Beck et al. [1] and Gostman et al. [2], indicate that periodontitis produces bacteremia, which is manifested in an increase in proinflammatory markers, TNFa, IL-1, IL6 and hsCRP. Buhlin et al. [3], Gani et al. [4] and in 2010 Nakajima et al. [5] refers to periodontitis is associated with limited levels of markers such as hsCRP and IL-6. On the other hand, D' Aiuto et al. [6] and Behle et al. [7], observe a significant reduction in inflammatory markers after periodontal treatment; even of PAI-1, VCAM-1 and MMP-9.
\end{abstract}

Background: The aim of this study is to determine the changes in serum levels of malondialdehyde, 8-hydroxy-2'-deoxyguanosine, hsCRP and fibrinogen as indicators of oxidative stress and inflammatory markers, in response to non-surgical periodontal treatment.

Case description: The patient, a 51-year-old male diagnosed with periodontitis was taken so as to be studied with a therapeutic objective, which should allow after three months the time of diagnosis and after non-surgical treatment. Topical doxycycline was used as adjunctive medication.

Conclusion: A significant reduction in both serum levels of pro-inflammatory markers and oxidative stress indicators is observed after periodontal treatment.

Previous studies have also shown improvements in proinflammatory markers, IL-6 and aTNF in patients to whom topical doxycyclin is applied $[8,9]$, which consequently shows inflammation modulating actions in its local application.

\section{Prooxidant markers}

The cells obtain energy through coupled oxidation-reduction (redox) reactions, during aerobic respiration. In this way, $\mathrm{O}_{2}$ is responsible for the formation of the so-called reactive oxygen species or ROS, which are molecules of high reactivity by having a missing electron [10]. NADPH oxidase primarily, they are also important xanthine oxidase (XO) and decoupled endothelial nitric oxide synthase (eNOS) [10] which promote ROS production and are involved in the development of vascular damage.

Inflammatory periodontal lesions present an important infiltrate of monocytes and macrophages, which has the purpose of containing the infectious process [11-17]. These defensive mechanisms will become an aggression for the periodontal tissues as a consequence of the production of free radicals (FR).

On the other hand, the nuclear factor NFkb, which is inactive in plasma due to the inhibitor Ikb. The degradation of this subunit, which is very sensitive to ROS, allows the promotion of the expression of genes that lead to the inflammatory response, this is a link between prooxidant states and chronic inflammatory processes [18].

When the free radicals react with a fatty acids molecule of the cellular lipid membranes [19], malondialdehyde (MDA) is generated, which is an indicator of tissue damage [20]. Another molecule that is damaged by free radicals is DNA, as a consequence of the arrival of ROS inside the cell nucleus, the action of the radical $\mathrm{OH}-$ is able to originate more than 20 modifications in the nitrogenous bases. We can highlight 8-hydroxy-2'-deoxyguanosine (8-OHdG), which is produced as a result of the interaction with guanine. It can be used like a marker of oxidative damage [21-29].

Therefore, serum concentrations of MDA and $8-\mathrm{OH}-\mathrm{dG}$ are increased in patients with periodontal disease as an expression of increased oxidative stress in the etiology of the lesions and their quantification, consequently, it will allow us to assess the prooxidant state.

\section{Case description}

The patient diagnosed with periodontitis was taken to be studied with a therapeutic objective, which should allow after three months, evidence of the effectiveness of periodontal treatment. Topical doxycycline was applied as an adjuvant in order to optimize the results and achieve the objectives set.

${ }^{\star}$ Correspondence to: Ricardo Andreu, Dental Clinic, Paterna, València, Spain, E-mail: r.andreu58@icloud.com

Key words: periodontal disease, periodontitis, inflammatory markers, 8-hidroxi2'-desoxiguanosine, malondialdehyde, oxidative stress

Received: September 10, 2020; Accepted: September 22, 2020; Published: September 28, 2020 


\section{Methodology}

\section{The work is structured in three parts:}

The first part will have analytical purposes and will consist of a periodontal study, which will be performed at the time of diagnosis, as well as a blood test to determine the serum level of hsCRP, fibrinogen, MDA and 8-OH-dG in urine.

The second part will have an interventionist character, in which all patients will undergo a nonsurgical periodontal treatment, topical doxycycline will be applied in lesions $\geq 5 \mathrm{~mm}$.

The third part will carry out a new periodontal study three months after having carried out the treatment, level of hsCRP, fibrinogen, MDA and $8-\mathrm{OH}-\mathrm{dG}$, will be determined again.

\section{Results}

A 51-year-old male, non-smoker, with no relevant pathological history, diagnosed with periodontal disease. The cut-off point for $\mathrm{PD} \geq$ $3 \mathrm{~mm}$ is the one most commonly used in the literature and in this study the CAL value $\geq 3 \mathrm{~mm}$ is used to establish the diagnosis according to the 2018 AAP-EFP criteria [30].

Underwent non-surgical periodontal treatment; the treatment in a single session or "full mouth" with the use of antiseptics and/or topical antibiotics in our case, have amply demonstrated clinical benefits [31], with topical application of doxycycline in periodontal lesions $\geq 5 \mathrm{~mm}$ and prospective follow-up, determining both clinical and biochemical parameters at the baseline and three months after the end of the treatment.

Baseline values: Clinical parameters: PD (mm) 3.47; CAL (mm) 3.77; \% PD 4 (mm) 59; \% PD 6 (mm) 4.86; BOP \% 27.27.

Biochemical parameters: hsCRP (mg/L) 0.28; Fibrinogen (mg/dL) 260; MDA $(\mu \mathrm{mol} / \mathrm{L}) 1.1 ; 8-\mathrm{OH}-\mathrm{dG}(\mu \mathrm{g} / \mathrm{g}) 11.9$.

Re-evaluation. Clinical parameters: PD (mm) 3.29; CAL (mm) 3.60; \% PD 4 (mm) 51; \% PD 6 (mm) 3.47; BOP\% 18.75.

Biochemical parameters: hsCRP (mg/L) 0.18; Fibrinogen (mg/dL) 214; MDA ( $\mu \mathrm{mol} / \mathrm{L})$ 0.7; 8-OH-dG $(\mu \mathrm{g} / \mathrm{g}) 6.1$.

Observed variation. Clinical parameters: PD (mm) -0.18; CAL (mm) -0.17; \% PD 4 (mm) -8; \% PD 6 (mm) -1.39; BOP\% -8.52.

Biochemical parameters: hsCRP (mg/L) $-0,1$; Fibrinogen $(\mathrm{mg} / \mathrm{dL})$ -46; MDA $(\mu \mathrm{mol} / \mathrm{L})-0.4 ; 8-\mathrm{OH}-\mathrm{dG}(\mu \mathrm{g} / \mathrm{g})-5.8$.

\section{Discussion}

The values of all the clinical parameters studied improve with respect to those observed at baseline, highlighting the decrease in the BOP index of $8.52 \%$. The determination of the BOP index, as an indicator of local inflammation, allows us, by contrasting it with the determinations of the biochemical parameters, to show its influence on the systemic inflammatory load and especially with the serum fibrinogen level [32].

A significant reduction in both serum levels of pro-inflammatory markers and oxidative stress indicators is observed after non-surgical periodontal treatment, especially fibrinogen in $-46(\mathrm{mg} / \mathrm{dL})$ and of $8-\mathrm{OH}-\mathrm{dG}$ in $-5.8(\mu \mathrm{g} / \mathrm{g})$.

Previous studies have also shown improvements in proinflammatory markers, IL-6, aTNF and oxidative stress [33,34] in patient receiving topical doxycyciclin $[35,36]$.
The application of topical doxycycline can contribute in this way by modulating actions of inflammation on its local application, as has been previously observed after its systemic administration at sub-therapeutic doses [37- 39].

In the present study, our results can be interpreted by the presence of a residual inflammatory load, a result of the aggression caused by periodontal treatment, which would lead to an increase in proinflammatory and oxidative stress markers, among them fibrinogen stands out and that given the immunomodulatory properties of doxycycline, the final balance results in a decrease in the values of serum levels of the different markers.

In summary, more studies with prospective and longitudinal characteristics, of greater size and duration, are necessary in order to more accurately objectify the influence of periodontal disease with systemic inflammation and, as a consequence, its relationship especially with chronic pathologies.

\section{Conclusion}

As a general conclusion of the present study, it can be affirmed that, as a consequence of periodontal treatment, there is a generalized improvement in clinical variables, pro-inflammatory markers and systemic pro-oxidants, at least in the short term.

This represents an important benefit, as a result of the reduction of the inflammatory load and systemic oxidative stress, with the consequent benefits for general health, without forgetting the alteration of the affinity for the nitrogenous bases of the oxidation products of guanine and therefore its possible mutagenic character.

\section{Consent}

As per international standard, patient's consent has been collected and preserved by the authors.

\section{Ethical approval}

As per international standard, written ethical approval has been collected and preserved by the author (s).

\section{Competing interests}

Authors have declared that no competing interests exist.

\section{References}

1. Beck JD, Eke P, Lin D (2005) Associations between IgG antibody to oral organism and carotid intima media media thickness in community dwelling adults. Atherosclerosis 183: 342-348. [Crossref]

2. Gostman I, Lotan CH, Soskolne WA, Rassovsky S, Pugatsch T, et al. (2007) Periodontal destruction is associated with coronary artery disease and periodontal infection with acute coronary syndrome. J Periodontol 78: 849-858. [Crossref]

3. Buhlin K, Hultin M, Norderyd O, Persson L, Pockley AG, et al. (2009) Risk factors for atherosclerosis in cases with severe periodontitis. J Clin Periodontol 36: 541-549. [Crossref]

4. Gani DK, Lakshmi D, Krishnan R, Emmadi P (2009) Evaluation of C-reactive protein and interleukin- 6 in the peripheral blood of patients with chronic periodontitis. J Indian SocPeriodontol 13: 69-74. [Crossref]

5. Nakajima T, Honda T, Domon H, Okui T, Kajita K, et al. (2010) Periodontitis associated up regulation of systemic inflammatory mediator level may increase the risk of coronary heart disease. J Periodontol 45: 116-122. [Crossref]

6. D'Aiuto F, Nabali L, Parkar M, Suvan J, Tonetti MS (2005) Short term effects of intensive periodontal therapy on serum imflammatory markers and cholesterol. $J$ Dent Res 84: 269-273. [Crossref]

7. Behle JH, Sedaghatfar MH, Demmer RT, Wolf DL, Celentin R, et al. (2009) Heterogeneity of systemic inflamatory responses to periodontal therapy. J Clin Periodontol 36: 287-294. [Crossref] 
8. Madi M, Pavlic V, Samy W, Alagl A (2018) The anti-inflammatory effect of locally delivered nano-doxycycline gel in therapy of chronic periodontitis. Acta Odontologica Scandinavica 76: 171-176. [Crossref]

9. Da Rocha HA, Silva CF, Santiago FL, Martins LG, Dias PC, et al. (2015) Local Drug Delivery Systems in the Treatment of Periodontitis: A Literature Review. J Int Acad Periodontol 17: 82-90. [Crossref]

10. Weswler AR, Bast A (2010) Oxidative Stress and Vascular Function: Implications for Pharmacologic Treatments. Current Hypertens Reports 12: 154-161. [Crossref]

11. Guarnieri C, Zuchelli G, Bernard F, Scheda M, Frezza R (1989) Polymorphonuclear neutrophilic granulocytes and the defense and damage of periodontal tissues. Minerva Stomatol 38: 783-794. [Crossref]

12. Shapira L, Borinski R, Sela MN, Soskolne A (1991) Superoxide formation and chemiluminescence of peripheral polymorphonuclear leukocytes in rapidly progressive periodontitis patients. J Clin Periodontol 18: 44-48. [Crossref]

13. Guarnieri C, Zuchelli G, Bernardi F, Scheda M, Valentini AF, et al. (1991) Enhancer peroxide production with no change of the antioxidant activity in gingival fluid of patients with chronic adult periodontitis. Free Radic Res Commun 15: 11-16. [Crossref]

14. Gustafsson A, Asman B (1996) Increased release of free oxygen radicals from peripheral neutrophils in adult periodontitis after Fc delta-receptor stimulation. $J$ Clin Periodontol 23: 38-44. [Crossref]

15. Ward PA (1998) Oxygen radicals inflammations and the tissue injury. Free Rad Biol Med 5: 403-408

16. Over C, Yamalik N, Yavuzyilmaz E, Ersoy F, Eratalay K (1993) Myeloperoxidase activity in peripheral blood, neutrophil crevicular fluid and whole saliva of patients with periodontal disease. J Nihon Univ Sch Dent 35: 235-240. [Crossref]

17. Firatli E, Unal T, Onan U, Sandai P (1994) Antioxidative activities of some chemotherapeutics. A posible mechanism in reducing gingival inflammation. $J$ Clin Periodontol 21: 680-683. [Crossref]

18. Bierhaus P, Schiekofer S, Schwaninger M, Andrassy M, Humpert P, et al. (2001) Diabetes associated sustained activation of the transcription factor nuclear factor-kb. Diabetes 50: 2792-2802. [Crossref]

19. Voskresenskii ON, Tkachenko EK (1991) The role of lipid peroxidation in the pathogenesis of periodontitis. Stomatologii Mosk 4: 5-10. [Crossref]

20. Kirkpatrick DT, Guth DJ, Malvis RD (1996) Detection of in vivo lipid peroxidation using hiobarbituric acid assay for lipid hydroperoxides. J Biochem Toxicol 1: 93-104. [Crossref]

21. Liu CS, Tsai CS, Kuo CL, Chen HW, Lii CK, et al. (2003) Oxidative stress-related alteration of the copy number of Biomarkers of oxidative stress study II: are oxidation products of lipids, proteins, and DNA markers of $\mathrm{CCI}(4)$ poisoning? Free Radic Biol Med 38: 698-710. [Crossref]

22. Kouda K, Nakamura H, Fan W, Horiuchi K, Takeuchi H (2001) The relationship of oxidative DNA damage marker 8-hydroxydeoxyguanosine and glycoxidative damage marker pentosidine. Clin Biochem 34: 247-50. [Crossref]

23. Kadiiska MB, Gladen BC, Baird DD, Germolec D, Graham LB, Parker CE, et al. (2005) 6 Biomarkers of oxidative stress study II: are oxidation products of lipids, proteins, and DNA markers of CCI(4) poisoning? Free Radic Biol Med 38: 698-710. [Crossref]
24. Jaruga P, Dizdaroglu M (1996) Repair of products of oxidative DNA base damage in human cells. Nucleic Acids Res 24: 1389-1394. [Crossref]

25. Guyton KZ, Kensler TW (1993) Oxidative mechanism in carcinogenesis. Brit Med Bul 49: 523-544. [Crossref]

26. Ohkawa H (1979) Assay for lipid peroxides in animal tissues by TBA reaction. Anal Biochem 58: 95-351. [Crossref]

27. Valavanidis A, Vlachogianni T, Fiotakis C (2009) 8-hydroxy-2'-deoxyguanosine (8OHdG): A Critical Biomarker of Oxidative Stress and Carcinogenesis. J Environ Sci Health C, Part C 27: 120-139. [Crossref]

28. Cadet J, Delatour T, Douki T, Gasparutto D, Pouget JP, et al. (1998) Hydroxyl radicals and DNA base damage. Mutat Res 424: 9-21. [Crossref]

29. Schmerold I, Niedermuller H (2001) Levels of 8-hydroxy-2'-deoxyguanosine in cellular DNA from 12 tissues of young and old Sprague-Dawley rats. Exp Gerontol 36: 1375-86. [Crossref]

30. Tonetti MS, Greenwell H, Kornman KS (2018) Periodontitis case definition: Framework for staging and grading the individual periodontitis case. Journal of Clinical Periodontology 45: 149-161. [Crossref]

31. Fang H, Han M, Li QL, Cao CY, Xia R, et al. (2016) Comparison of a full- mouth disinfection and quadrant-wise scaling in the treatment of adult chronic periodontitis: a systematic review and meta-analysis. J Periodontal Res 51: 417-430. [Crossref]

32. Andreu R (2020) Effects of topical doxycycline on inflammatory markers in periodontal disease. Clin Sci Res Rep 3: 1-3.

33. Muthuraj MSA, Janakiram S, Chithresan K, Maradi AP, Maddur PK, et al. (2017) Effect of scaling and root planing on levels of 8-hydroxydeoxyguanosine in gingival crevicular fluid of chronic periodontitis patients with and without Type II diabetes mellitus. J Indian Soc Periodontol 21: 201-206. [Crossref]

34. Bansal N, Gupta ND, Bey A, Sharma VK, Gupta N, et al. (2017) Impact of nonsurgical periodontal therapy on total antioxidant capacity in chronic periodontitis patients. $J$ Indian Soc Periodontol 21: 291-95. [Crossref]

35. Marwa M, Verica P, Wael S, Adel A (2018) The anti-inflammatory effect of locally delivered nano-doxycycline gel in therapy of chronic periodontitis. Acta Odontologica Scandinavica 76: 171-176. [Crossref]

36. Da Rocha HA, Silva CF, Santiago FL, Martins LG, Dias PC, et al. (2015) Local Drug Delivery Systems in the Treatment of Periodontitis: A Literature Review. $J$ Int Acad Periodontol 17: 82-90. [Crossref]

37. Emingil G, Gurkan A, Tervahartiala T, Hernandez M, Ozgul S, et al. (2019) Adjunctive Effects of a Sub-Antimicrobial Dose of Doxycycline on Clinical Parameters and Potential Biomarkers of Periodontal Tissue Catabolism. Dent 7: 9. [Crossref]

38. Izuora KE, Ezeanolue EE, Neubauer MF, Gewelber CL, Allenback GL, et al. (2016) Changes in Inflammatory and Bone Turnover Markers After Periodontal Disease Treatment in Patients with Diabetes. Am J Med Sci J 351: 589-594. [Crossref]

39. Bretz WA (2012) Low-dose doxycycline plus additional therapies may lower systemic inflammation in postmenopausal women with periodontitis. J Evid Based Dent Pract 12: 67-68. [Crossref]

Copyright: (C2020 Andreu R. This is an open-access article distributed under the terms of the Creative Commons Attribution License, which permits unrestricted use, distribution, and reproduction in any medium, provided the original author and source are credited. 